\title{
The differentiated teaching English-speaking interaction to prospective teachers
}

\author{
M. Shcherbyna, O. Bigych
}

Kyiv National Linguistic University, Kyiv, Ukraine

Corresponding author. E-mail: madina70@ukr.net

Paper received 12.10.19; Accepted for publication 29.10.19.

\begin{abstract}
ttps://doi.org/10.31174/SEND-PP2019-207VII84-08
\end{abstract}
\begin{abstract}
Among the techniques of foreign languages and cultures teaching, the technology of differentiated teaching is recognized. We realize internal differentiation of English-speaking interaction teaching in the context of the learner-centered approach while educating prospective teachers. We distinguish the motivation-affective, cognitive, and emotion differentiation. Thus, the cognitive differentiation includes two more subtypes such as the receptive-cognitive differentiation and the reproductive-cognitive one. Every type of the differentiation has its inherent mean of diagnostics and implementation.
\end{abstract}

Keywords: differentiation, English, prospective teachers, speaking interaction.

Introduction. Each higher education lecturer is looking for new teaching technologies to form their students' foreign communicative target competences more effectively. Among the techniques of foreign languages and cultures teaching in higher education institutions, the technology of differentiated teaching is worth being investigated. Thus, the differentiated approach enables teaching students by means of the programs based on self-learning.

Literature review. Babanskii [2, p. 17] defines the differentiated approach to teaching as matching of all the study components and students' abilities, especially their skills and level of knowledge.

Unt [12] distinguishes differentiated and individualized instruction. According to the scientist, individualized instruction is a teaching approach due to which teachers involve their students' individual characteristics by means of different teaching techniques. However, differentiated teaching turns out to be a way of individualized instruction realization by grouping students due to their similar characteristics.

Artiuhov [1, p. 11] claims that differentiated teaching is a special educational system with its subsystem of teaching that involves both individual and prevailing group characteristics.

Sikorskii [11, p. 19] distinguishes between terms differentiated approach, differentiated teaching, and differentiation of teaching. The scientist explains that the differentiated approach is applied when a teacher diversifies educational components. Differentiated teaching is pedagogical collaboration between a teacher and a student, where student's individual characteristics are recognized and developed. Differentiation of teaching is students' grouping by some criteria and further adaptation of study context, methods, and forms to each typological group.

In the context of modern methodology, differentiation can be internal and external. Artiuhov [1, p. 11] explains that external differentiation is realized by means of grouping students' due to their age, interests, and specialty. Specialized classes, different types of educational institutions, specialties etc. exemplify external differentiated teaching.

Internal differentiation requires educational and methodological work within studying group to solve the problem of its diversity considering individual characteristics of each student [17, p. 7].

In this research, we are aimed at internal differentiation of teaching English-speaking interaction to prospective teachers. Therefore, it is important to choose the criteria we are going to group students by. However, the scientists mentioned above have not found out unified criteria yet.

Osmolovska [10] suggests grouping students due to their creative skills. Babanskii [2] and Humankova [7] find it effective to group students by their knowledge and skills. Honey and Mumford [18], and Gardner [16] investigate the differentiated teaching based on cognitive (learning) styles [7, pp. 167-170]. Nevertheless, the criteria suggested in the previous research are lack of systematic approach.

The aim of the article is to organize criteria which students can be grouped by and introduce an authorial methodology of differentiated teaching English-speaking interaction to prospective English teachers.

Materials and methods. To make grouping more organized and systematic, we [6] realize the methodology of differentiated teaching of English-speaking interaction in the context of the learner-centered approach.

Due to the learner-centered approach, a student's development includes motivational, intellectual (cognitive), emotional, studying, and communicative aspects of their personalities. Thus, we apply different criterion depending on the aspect considered and form typological groups of students while teaching them English-speaking interactive communication. In addition, a chosen criterion predetermines a type of differentiated teaching English-speaking interactive competence.

Thus, students' motives to study English-speaking interaction, their cognitive processes, and emotions involved are the criteria that we group students by. Consequently, we distinguish motivational, cognitive, and emotional [5] types of differentiated teaching English-speaking interaction. Moreover, we distinguish between receptive-cognitive differentiation [13, pp. 128-134] and reproductive-cognitive differentiation [15, pp. 139-145].

Stages of teaching speaking interaction. Top-down processing of teaching foreign speaking interaction $[4$, p. 318] provides for listening an example of a pattern dialogue first and its further transformation. Students eventually make their own creative conversations.

Therefore, there are four stages of speaking interaction competence development, such as turn-taking, adjacency pair exchange, mini-dialogue making, a conversation making [4, pp. 318-319]. Following Metiolkina [9, p. 9], we find it necessary to add a preparatory stage aimed at listening a pattern dialogue.

Thus, the methodology of differentiated teaching English-speaking interaction that is introduced in this research involves such stages as the preparatory stage, the first stage, and the second stage. 
At the preparatory stage, students listen to a pattern dialogue and enact some of its parts practicing turn-taking. Then, they combine turns into adjacency pairs mastering their communicative skills.

At the first stage, gained at the preparatory stage knowledge, students reproduce while developing communicative skills of making mini dialogues. A teacher should provide their students with learning prompts, which may be visual, spoken, or written, for greater efficiency.

At the second (final) stage, students practice making a conversation (dialogue) of a learned functional type.

\section{Diagnostic means and students' typological groups.} In order to form typological groups of students, we implemented several diagnostic methods. First, we conducted a questionnaire to find out the students' motives for learning speaking interaction and divide them into groups such as "Inner-motivated students" and "Outer-motivated students".

According to the questionnaire, $46 \%$ of the students have inner motives for learning English-speaking interaction, whereas only $25 \%$ are influenced by their outer motives. The rest of the respondents $(29 \%)$ have both types of learning motivation involved on the same level. The results of the survey prove that outer and inner motivation affect a student simultaneously [8, pp. 34-35]. It is important to mention that the predominance found out in one of the groups is little. Thus, it is wrong to believe that students are charged by one type of the learning motives.

Secondly, we conducted a survey to examine students' dominant sensor modality and divide them into visual, audial, and kinesthetic learners. The results show that $46 \%$ of the students are so called audials, $33 \%$ - visuals, and $21 \%$ kinesthetic learners. However, the majority of respondents seem to have multi-modal perception with insignificant domination of visual or audial reception. According to the survey results, following Beliavskaia [3, p. 34], we believe that for better study performance teaching should be multimodal, though, with an emphasis on a dominant perception channel.

In addition, we tested students to measure the activity of their verbal and visual thinking and group them accordingly. $55 \%$ of the examined students coped with verbal tasks better and faster than with illustrative ones. $45 \%$ showed an opposite result.

As a result, we introduced the following typological groups:

- "inner-motivated" and "outer-motivated" students by their dominant motives for studying English-speaking interaction;

- "audials", "visuals", and "kinesthetics" by their dominant perceptive modality;

- "verbally oriented" and "visually oriented" students by their dominant type of thinking.

At each stage of the teaching English-speaking interaction, we provided every typological group of students with differentiated teaching technique.

The receptive-cognitive differentiation. At the preparatory stage, we provide all the students with both recorded and printed versions of a pattern dialogue to realize multi modal perception of the information studied. "Audials" listen to a pattern dialogue first and enact it while practicing turn-taking or making adjacency pairs taken out of the record and printed in the context of exercises. "Visuals" should work on the printed text first, where their attention should be drown to initiative and reactive turns colored differently, highlighted etc. As concerns "kinesthetics", they should enact a pattern dialogue by reading its script with movements, emotions, and props if possible.

Even though we realize multi-modal perception this way, the first information flow is targeted at a dominant perceptive channel. Thus, the mean of realization of the receptive-cognitive differentiation at the preparatory stage of teaching English-speaking interaction is a providing format of a pattern dialogue.

The reproductive-cognitive differentiation. While investigating educational potential of a comic strip [14], we found out that its creolized nature had positive impact on students' studying by activating their different cognitive processes and two channels of perception. Thus, we suggest a comic strip as means of realization of reproductivecognitive differentiation while teaching students Englishspeaking interaction.

At the first stage, while students create their own mini dialogues, depending on their dominant type of thinking, they get different comic strips as learning prompts. The students with dominant verbal thinking use self-made black-and-white comic strips where verbal component prevails (Figure 1). Oversaturation of pictures and other colors may distract such students' attention, while exercises aimed at filling the gaps or making turns contribute to their verbal cognition.

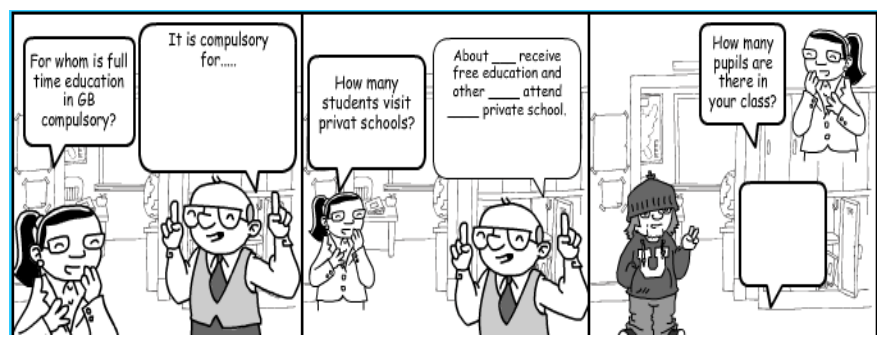

Fig. 1. Learning comic strip for students with dominant verbal thinking

On the contrary, it is important that students with more developed visual thinking get colorful comic strips with a greater part of illustrations and reduced verbal component (Figure 2). Otherwise, the latter one can either overload or distract such students' attention having negative impact on their studying performance. Thus, all the lines should be given apart from a comic strip (e.g. in a table). The students create mini dialogues filling the gaps with necessary lines, ordering panels chronologically, adding self-made images etc.

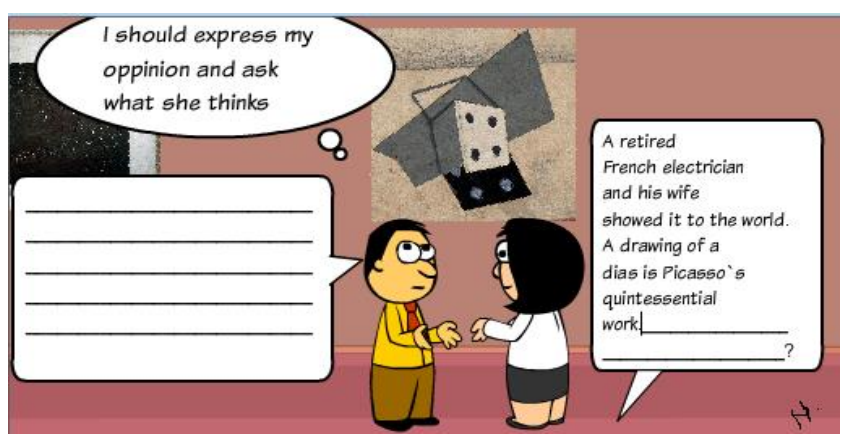

Fig. 2. Learning comic strip for students with dominant visual thinking 
We introduced an algorithm (Table 1) for the application of a comic strip while teaching English-speaking interaction to students with either visual or verbal dominant way of thinking.

Hence, verbal and illustrative components of a comic strip make it possible to apply differentiation by dominant type of students' thinking at the English class. Consequently, we suggest that a comic strip be means of realization of reproductive-cognitive differentiation while teaching students English-speaking interaction at the stage of their making mini dialogues.

The motivation-affective differentiation. At the second stage, students create their own dialogues playing role games. First, by means of questionnaire, we divide students into two groups depending on their dominant (inner or outer) learning motives.

Students with prevailing outer motivation get a task to make a conversation due to communicative situations which reflect their everyday social life or refer to future profession: job interview, seeing a doctor, conversation with a friend etc.

However, students whose prevailing motives are inner ones enact non-standard situations (e.g. time-travel, space research etc.) In that case, students have to apply more creativity and additional extra-linguistic knowledge.

Thus, a communicative situation is considered to be a means of motivation differentiation at the point of students making their own dialogues.

Table 1. Algorithm for the application of a comic strip as means of reproductive-cognitive differentiation realization

\begin{tabular}{|c|c|c|}
\hline & Typological group of "verbally oriented" students & Typological group of "image oriented" students \\
\hline \begin{tabular}{|c|} 
Presentation of \\
verbal component in \\
a comic strip
\end{tabular} & $\begin{array}{l}-\quad \text { verbal component prevails over images in its amount; } \\
\text { - }\end{array}$ & $\begin{array}{ll}- & \text { reduced verbal component; } \\
\text { - } & \text { usage of creative colors and prints }\end{array}$ \\
\hline $\begin{array}{c}\text { Presentation of } \\
\text { images in a comic } \\
\text { strip }\end{array}$ & $\begin{array}{ll} & \text { reduced number of images; } \\
- & \text { a black-and-white comic strip; } \\
- & \text { unfilled speech bubble occupies a greater part of a panel }\end{array}$ & $\begin{array}{ll}- & \text { bright images rendering involving plot; } \\
\text { - } & \text { greater number of illustrative details; } \\
- & \text { space for self-made images / sketches }\end{array}$ \\
\hline Exercises & $\begin{array}{l}\text { - lines transformation; } \\
\text { - lines extension }\end{array}$ & $\begin{array}{l}\text { - chronological or logical sequence of panels; } \\
\text { - } \text { matching lines with images; } \\
\text { - } \text { adding self-made images to given lines }\end{array}$ \\
\hline
\end{tabular}

What is more, in order to make friendly and comfortable atmosphere for students working in pairs, we consider diversity of their temper [5].

Sthenic type is characterized by greater activity, constant desire for activity, initiative, and prevailing positive emotions. Asthenic type is quite indifferent and suffers from negative emotions or weakness.

Facing failures, emotionally strong students can resist stress; they are always ready for new tasks. On the contrary, affective students tend to have too emotional unexpected reactions hard to be predicted at class.

Passionately involved students seek constant activity; they are always excited and express great interest in studying no matter what they have to do. However, students who are less motivated should enact different roles not to get bored at class. They are more likely to act as professionals discussing field they are good at.

Being sociable and expansive, extraverts adapt to all the changes in the surrounding fast; they tend to make quick decisions and gain new skills sooner than the others. Such students should get leading roles. At the same time, introverts are internally focused people. They are involved into studying activity and appear to prolong its preparatory stages to understand a task better. They happen to be at the bottom of a social ladder in a group more frequently than extraverts.

Hence, the means of realization of emotional differentiation at the stage of making dialogues are the roles that are proposed by the lecturer.

Since motivation differentiation and differentiated teaching by emotions (temper) are implemented at the same stage and by means of a role-play, we find it possible to unite them into motivation-affective differentiation.

Conclusions. The authorial methodology of differentiated teaching English-speaking interaction to students is concluded and introduced in Table 2.

Table 2. The methodology of differentiated teaching English-speaking interaction to students

\begin{tabular}{|c|c|c|c|}
\hline Learning stage and its content & $\begin{array}{c}\text { Type of differentia- } \\
\text { tion }\end{array}$ & Diagnostic tool & Means of realization \\
\hline $\begin{array}{c}\text { Preparatory stage: } \\
\text {-listening to a pattern dialogue; } \\
\text {-turn-taking and adjacency pair exchange }\end{array}$ & $\begin{array}{c}\text { The receptive- } \\
\text { cognitive differentiation }\end{array}$ & Survey & $\begin{array}{c}\text { Format for presenting a } \\
\text { pattern dialogue }\end{array}$ \\
\hline $\begin{array}{c}\text { The first stage - } \\
\text { making a mini-dialogue }\end{array}$ & $\begin{array}{c}\text { The reproductive- } \\
\text { cognitive differentiation }\end{array}$ & Testing & A comic strip \\
\hline $\begin{array}{c}\text { The second stage - } \\
\text { making a dialogue }\end{array}$ & $\begin{array}{c}\text { The motivation- } \\
\text { affective differentiation }\end{array}$ & Questionnaire & $\begin{array}{c}\text { A communicative role } \\
\text { play }\end{array}$ \\
\hline
\end{tabular}

In this way, we introduced theoretical basis and practical value of the receptive-cognitive, reproductive-cognitive, and motivation-affective differentiation of teaching English-speaking interaction to prospective teachers; organized criteria students should be grouped by at every stage of their studying English-speaking interaction, introduced authorial methodology of differentiated teaching Englishspeaking interaction to prospective teachers with another subtype of differentiation at every stage. The further aim of our research is to investigate a professional component of differentiated teaching English-speaking interaction to prospective teachers.

\section{ЛИТЕРАТУРА}


2. Бабанский Ю. К. Оптимизация учебно-воспитательного процесса (методические основы) [Текст] / Ю. К. Бабанский. - Москва: Просвещение, 1982. - 192 с.

3. Белявська О. О. Перцептивні стилі - запорука ефективного навчання / О. О. Белявська // Педагогічна освіта: теорія і практика. - 2015. - Вип. 18. - С. 30-36.

4. Бігич О. Б., Бориско Н. Ф., Борецька Г. Е. та ін. Методика навчання іноземних мов і культур: теорія і практика: підручник для студ. класичних, педагогічних і лінгвістичних університетів / Бігич О. Б., Бориско Н. Ф., Борецька Г. Е. та ін./ за загальн. ред. С. Ю. Ніколаєвої. - К.: Ленвіт, 2013. $590 \mathrm{c}$.

5. Бігич, О. Б. і Щербина, М. Б. (2017). Формування англомовної компетентності в діалогічному мовленні майбутніх учителів: емоційна диференціація. В Тенденції та перспективи розвитку науки і освіти в умовах глобалізації. (сс. 274-276). Переяслав Хмельницький.

6. Бігич, О.Б., Щербина, М.Б. (2017). Особистіснодіяльнісний підхід до формування іншомовної комунікативної компетентності. В аспекті гуманізуючого впливу освіти на особистість. Матеріали міжнародної науковопрактичної конференції до 100-річчя Дніпровського національного університету імені Олеся Гончара, 25-27 жовт. (сс. 76-78). Дніпро: Літограф.

7. Гуманкова О. С. Реалізація диференційованого навчання у процесі професійно-методичної підготовки майбутніх учиО. С Гуманкова // Збірник наукових праць [Херсонського державного університету]. Педагогічні науки. - 2016. Вип. 74(1). - С. 166-170

8. Докучина, Т. О. (2011). Мотивація навчання як запорука стимулювання учнів до досягнення успіху. Педагогічна освіта: теорія і практика, 8, С. 32-36.

9. Метьолкіна О. М. Формування англомовної професійно орієнтованої компетенції у діалогічному мовленні майбутніх митників [Текст]: автореф. дис.... канд. пед. наук: сс.... канд. пед. наук. - Новокузнецк, 1996.- 23 с. телів англійської мови дошкільних навчальних закладів /

13.00.02 / Метьолкіна Олена Миколаївна ; Нац. пед. ун-т ім. М. П. Драгоманова. - К., 2012. - 21 с.

10. Осмоловская И. М. Организация дифференцированного обучения в современной общеобразовательной школе / И. М. Осмоловская; Акад. пед. и социал. наук, Моск. психол.социал. ин-т, Ин-т практ. психологии. - Москва; Воронеж: Модэк, 1998. - 155 с.

11. Сікорський П. І. Теорія і методика диференційованого навчання в середніх загальноосвітніх і професійних навчальних закладах [Текст]: дис... д-ра пед. наук: 13.00.04 / Сікорський Петро Іванович ; Ін-т педагогіки і психології проф. освіти АПН України. - К., 2001.

12. Унт И. Э. Индивидуализация и дифференциация обучения. / И. Э. Унт. - М.: Педагогика, 1990. - 192 с.

13. Щербина М. Б. Рецептивно-когнітивна диференціація формування компетентності в англійському діалогічному мовленні: теоретичне обгрунтування й засоби реалізації / М. Б. Щербина // Вісник Київського національного лінгвістичного університету. Серія Педагогіка та психологія. Вип. 29. - 2019. - С. 128-134.

14. Щербина М. Б. Формування іншомовної комунікативної компетентності майбутніх учителів іноземних мов засобами коміксів / М. Б. Щербина // Іноземні мови. - 2016. - № 1. - С. 31-36.

15. Щербина М. Б. Репродуктивно-когнітивна диференціація формування у майбутніх учителів англомовної компетентності в діалогічному мовленні: теоретичне обгрунтування й засоби реалізації // Вісник Київського національного лінгвістичного університету. Серія Педагогіка та психологія. - Вип. 30. - 2019. - 139-145.

16. Gardner, H. 2004. Multiple Intelligences: New Horizons in Theory and Practice. NY: Ingram publisher services US.

17. Heymann, H. W. 2010. Binnendifferenzierung - eine Utopie? Pädagogischer Anspruch, didaktisches Handwerk, Realisierungschancen. Weinheim: Pädagogik, no. 11: 6-11.

18. Honey, P. and Mumford A. 1992. The Manual of Learning Styles. London: Maidenhead.

\section{REFERENCES}

1. Artiuhov, M. V. 1996. Differentiated instruction for students at an industrialized region. $\mathrm{PhD}$ diss., Novokuznetsk State Pedagogical Institute.

2. Babanskii, I. K. 1982. The system of the ways to optimize teaching. Voprosi psihologii, no. 5: 12-22.

3. Beliavskaia, O. 2015. Perceptual styles as the key to effective learning foreign languages, no. 18: 30-36.

4. Bigych, O. et al. 2013. Metodika navchannia inozemnih mov i kultur: teoriia ta praktika: pidruchnik dlia stud. Nikolaieva, S., ed. Kyiv: Lenvit.

5. Bigych, O. and Shcherbyna, M. 2017. Development of prospective teachers': emotion differentiation. Paper presented at the $30^{\text {th }}$ international scientific online-conference Tendentsii ta perspektivi rozvitku nauki y osviti $v$ umovah globalizatsii, Pereiaslav-Khmelnitskii, November 28. Accessed August 21, 2019. http://confscientific.webnode.com.ua

6. Bigych, O. and Shcherbyna, M. 2017. Learner-centered approach to foreign communicative competence. $\mathrm{V}$ aspekti humanizuiuchoho vplyvu osvity na osobystist'. Published materials of the international scientific conference dedicated to the $100^{\text {th }}$ anniversary of Oles Honchar Dnipro National University, October 25-27. Dnipro: Litohraf, 76-78.

7. Humankova O. 2016. The realization of the differentiated instruction in the process of prospective preschool English language teachers' professional methodological training. Pedagogichni nauki, no. 74: 166-170.
8. Dokuchyna, T. 2011. Motivated studying as the key to encourage students to succeed. Pedahohichna osvita: teoriia i praktyka, no. 8: 34-35.

9. Metiolkina, O. 2012. Developing in future custom officers professionally oriented competence in English dialogical speech. PhD diss., Dragomanov National Pedagogical University.

10. Osmolovska, I. M. 2005. The organization of differentiated teaching at modern comprehensive school. Moscow: Moscow Psychological and Social Institute.

11. Sikorskii, P. I. 2001. Theory and methods of differentiated instruction in secondary and professional educational institutions. PhD diss., Pedagogics and Psychology Institute of Professional Education, Ukrainian Academy of Pedagogics.

12. Unt, I. 1990. Individualization and differentiated teaching. Moscow: Pedagogika.

13. Shcherbyna, M. 2016. Development of foreign language communicative competence by means of comic strips. Inozemni movy, no. 1: 31-36.

14. Shcherbyna, M. 2018. The development of the Englishspeaking interaction competence of the prospective teachers by means of receptive-cognitive differentiation. Visnyk KNLU. Series Pedagogy and psychology, no. 29: 128-134.

15. Shcherbyna, M. 2019. The development of the Englishspeaking interaction competence of the prospective teachers by means of reproductive-cognitive differentiation. Visnyk KNLU. Series Pedagogy and psychology, no. 30: 139-145. 